\title{
PENGELOLAAN SAMPAH ORGANIK DAN ANORGANIK DI DESA LENGKONG KULON KABUPATEN TANGERANG
}

\author{
Dyah Ayu Anggreini Tuasikal', Ahmad Syahril Muharom², Dwi Dharma Arta Kusuma ${ }^{3}$, \\ Indiwan Seto Wahjuwibowo ${ }^{4}$, M.B Nugraha ${ }^{5}$, M. Shobri ${ }^{6}$ \\ 1,2,3,4,5 Universitas Multimedia Nusantara \\ dyah.ayu@umn.ac.id, ahmad.syahril@umn.ac.id, dwi.arta@lecturer.umn.ac.id, indiwan@umn.ac.id, \\ mb.nugraha@umn.ac.id,obie.st3@gmail.com
}

\begin{abstract}
Abstrak
Abstrak Jumlah area Desa Lengkong Kulon adalah $15331 \mathrm{~km}^{2}$. Desa Lengkong Kulon ini merupakan desa berkembang yang pada saat ini wisata yang akan dikembangkan pada desa ini adalah wisata religi, wisata kuliner, wisata air, dan dari segi ekonomi. Namun dari beberapa pengembangan tersebut, desa ini membutuhkan pengelolaan sampah. Sampah merupakan hal krusial bagi kehidupan dan kesehatan masyarakat. Di area yang luas tersebut terdiri dari beberapa RW yang memiliki kebijakan tersendiri untuk pengelolaan sampahnya. Ada yang melakukan pembakaran sampah, ada yang bekerjasama dengan pemerintah daerah untuk pengangkutan sampah, dan ada pula yang membuang sampah pada lahan kosong. Dari segi kesehatan untuk proses pembakaran sampah dan membuang sampah sembarangan memiliki dampak buruk, karena dapat mengakibatkan pencemaran lingkungan bagi masyarakat sekitar. Solusi yang ditawarkan dengan Program Kemitraan Masyarakat ini adalah dengan memberikan penyuluhan terkait pengolahan sampah, peminjaman mesin pencacah sampah organik dan anorganik, dan pengawasan dalam pemanfaatan mesin tersebut. Desa Lengkong Kulon memiliki bank sampah yang akan dikelola oleh pemuda-pemudinya. Bank Sampah ini adalah wadah bagi masyarakat untuk mengubah sampah yang mereka miliki menjadi uang. Dengan adanya mesin pengolah sampah, maka harga jual sampahnya akan lebih tinggi dibandingkan jika penjualan sampah sebelum diolah.
\end{abstract}

Kata Kunci : Sampah, organik, anorganik, pengolahan.

\section{PENDAHULUAN}

Indonesia merupakan salah satu negara berkembang yang berarti sebagian besar penduduknya menggantungkan mata pencahariannya pada bidang pertanian (Ministry of Agriculture, 2014). Sebagai negara berkembang perpindahan mata pencaharian kepada perkantoran, perindustrian dan pariwisata membuat tatanan masyarakat dan gaya hidup berubah. Salah satu desa binaan Universitas Multimedia Nusantara (UMN) yaitu Desa Lengkong Kulon merupakan desa berkembang yang pada saat ini memiliki rencana pengembangan di bidang wisata, kuliner, dan kerajinan tangan. Saat ini Kabupaten Tangerang sedang mencanangkan Smart City untuk menjadikan Kabupaten Tangerang menjadi kawasan yang dapat mengelola berbagai sumber dayanya secara efektif dan efisien. Pemanfaatan sumber daya tersebut untuk menjawab banyak tantangan terkini dengan memanfaatkan solusi yang inovatif, terintegrasi, dan berkelanjutan. Solusi tersebut bertujuan untuk menyediakan infrastruktur dan memberikan layananlayanan untuk meningkatkan kualitas hidup warga di daerah tersebut. 
Untuk menjalankan tujuan besar tersebut, perlu didukung dari lingkup yang lebih kecil. Menurut data pemerintahan Kabupaten Tangerang terdiri dari 29 Kecamatan, 246 Desa, dan 28 Kelurahan [1]. Dari salah satu desa yang berada di kawasan Kabupaten Tangerang, Lengkong Kulon sedang dalam proses menjadikan desa ini sebagai salah satu desa yang akan menerapkan konsep Smart Village. Untuk melaksanakan konsep tersebut segala aspek yang berada di desa tersebut harus dibenahi terlebih dahulu, agar dapat terlaksana dengan baik.

Salah satu faktor pendukung aspek Smart Village adalah pengelolaan limbah masyarakat baik berupa sampah organik maupun anorganik. Pengelolaan sampah organik maupun anorganik merupakan suatu faktor pendukung utama. Apabila sampah ini tidak dikelola dengan baik, dapat mengakibatkan beberapa akibat yaitu: 1) Sampah bisa menyebabkan pencemaran udara karena terdapat gas-gas yang menimbulkan bau yang tidak sedap; 2) Penumpukan sampah mengakibatkan kondisi ketidaknyamanan kehidupan lingkungan sekitarnya; 3) minim oksigen terjadi karena selama proses perombakan sampah menjadi senyawasenyawa yang diperlukan oksigen yang telah diambil dari udara sekitar tempat pembuangan sampah; 4) gas yang dihasilkan selama proses pembusukan sampah bisa membahayakan kesehatan karena bisa jadi sampah tersebut mengandung gas beracun; 5) menyebabkan terjadinya penularan penyakit melalui hewan, misalnya lalat atau serangga lain; 6) Tempat pembuangan sampah menjadi tempat yang kurang indah dipandang dan lingkungan tersebut tidak nyaman untuk dihuni [5].

Dimana pada awalnya pengelolaan sampah hanya dibuang kemudian jika diolah dengan teknologi tepat guna menjadi komoditi tertentu. Pengelolaan sampah merupakan suatu hal yang berkaitan dengan pengaturan terhadap penyimpanan sementara, penimbunan, pemindahan, pengumpulan, pengangkutan, dan pemrosesan sampah[2]. Sebagai contoh pengelolaan sampah organik menjadi pupuk atau tanah humus. Kemudian pengelolaan sampah anorganik yang pada awalnya berupa botol plastik menjadi potongan bijih plastik yang siap menjadi komoditi bahan baku. Hasil olahan plastik bisa dimanfaatkan sebagai kerajinan tangan yang nantinya bisa meningkatkan perekonomian warga

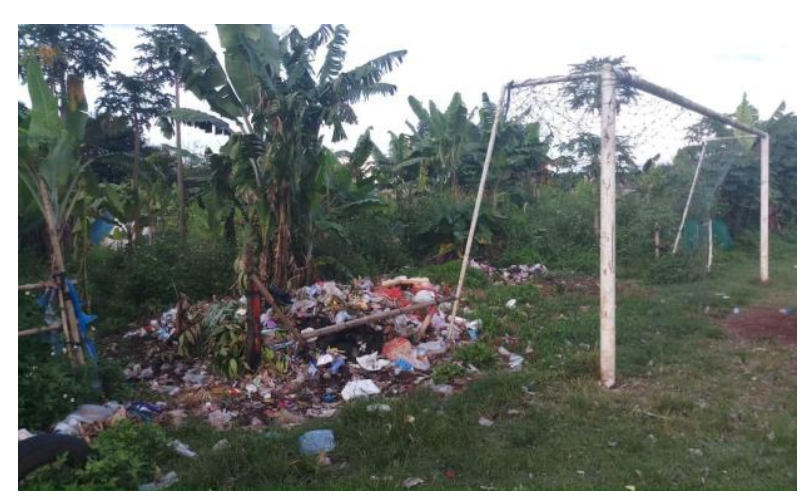

Gambar 1. Kondisi pembuangan sampah di Desa Lengkong Kulon

[4]. Sebagai contoh lain dalam pengelolaan sampah yang terkumpul dapat dilakukan dengan tiga cara yaitu dengan menimbun di tempat tertentu, dengan menggabungkan, dan mendaur ulang atau biasa disebut recycling [3][6].

Ada beberapa prinsip yang bisa diterapkan pada pengelolaan sampah. Prinsip ini dikenal dengan 4M, 4M adalah 1) mengurangi (reduce) meminimalisasi barang yang kita pergunakan; 2) menggunakan kembali (reuse) yang mana barang tersebut bisa dipakai kembali atau mengurangi memakai bahan yang hanya bisa digunakan sekali; 3) mendaur ulang (recycle) menggunakan kembali barang-barang yang sudah tidak berguna; 4) mengganti, meneliti barang dan mengganti ke barang yang lebih tahan lama [7].

Kegiatan PKM yang dilaksanakan di desa ini berkaitan dengan RIP dan Renstra PKM yaitu teknologi tepat guna yang menghasilkan produk olahan yang dapat membantu perekonomian warga sekitar Desa Lengkong Kulon. Walaupun perkembangan Desa Lengkong Kulon sangat baik, ada sektor penting yang tak kalah pentingnya yaitu dari segi pengelolaan sampah. Kebetulan pada desa lengkong kulon ada beberapa masyarakat yang kurang dari segi ekonomi, yang mengakibatkan mereka tidak bisa membayar kepada Dinas Kebersihan sekitar untuk melakukan pengangkutan sampah. Proses pengolahan sampah ini tidak hanya untuk kebersihan tetapi bagi keindahan dan kesehatan seluruh masyarakat sekitar Desa Lengkong Kulon yang masih belum memiliki penanganan sampah di RW tempat tinggalnya. 
Harapannya dapat dilakukan di seluruh RW di desa tersebut. Agar sistem pengolahan sampah ini dapat dirasakan merata pada desa tersebut. Berikut adalah gambaran kondisi sampah yang ada di desa Lengkong Kulon saat ini.

Tujuan dan manfaat dari PKM ini adalah untuk membantu desa lengkong kulon dari segi pengelolaan sampah. Pengelolaan ini untuk sampah organik seperti kertas dan plastik atau bisa diolah menjadi kerajinan tangan. Untuk sampah anorganik seperti sisa makanan dan kulit buah. Dari sampah tersebut bisa dijadikan pupukSelain itu hasil dari pengelolaan ini bisa dijual dan menghasilkan uang yang digunakan untuk mengembangkan Desa Lengkong Kulon menjadi lebih baik.

Solusi yang ditawarkan dengan Program Kemitraan Masyarakat ini adalah dengan membuat sistem pengolahan sampah terpadu. Kami akan memberikan penyuluhan tentang bagaimana pengelolaan sampah yang baik pada lingkungan Desa Lengkong Kulon. Pemanfaatan hasil olahan tersebut akan dinikmati oleh masyarakat desa tersebut.

Selain meminjamkan mesin pencacah sampah organik dan anorganik, kami kaan memberikan pelatihan kepada beberapa orang yang ditunjuk sebagai tim pengelola sampah. Tim ini yang nantinya akan diberikan pengetahuan bagaimana cara menggunakan dengan baik mesin tersebut. Tak hanya cara menggunakan, kami juga akan memberikan penyuluhan bagaimana cara merawat dan maintenance mesin jika terjadi kerusakan. Jadi setelah kita melakukan kegiatan PKM ini maka masyarakat sudah siap untuk menjalankan semua proses pengelolaan sampah tanpa harus repot-repot menunggu tim dari Universitas Multimedia Nusantara untuk datang dan memperbaiki mesin tersebut.

Target luaran dari Program Kemitraan Masyarakat ini adalah peningkatan penerapan IPTEK di masyarakat (mekanisme dan IT, dan manajemen) dan untuk perbaikan tata nilai masyarakat dari segi sosial, ketentraman, pendidikan, dan kesehatan.

\section{METODE}

Program ini dilaksanakan di Desa Lengkong Kulon, Kecamatan Pagedangan, Kabupaten Tangerang selama 1 tahun dari bulan Maret 2019 sampai Maret 2020. Kegiatan pelaksanaan Pengabdian kepada Masyarakat untuk pengelolaan sampah ini adalah sebagai berikut.

\section{Survey Lokasi}

Tahap pertama adalah melakukan pengecekan lokasi desa tersebut. Melakukan pengecekan area tempat pembuangan sampah. Selanjutnya dipetakan area yang akan digunakan untuk tempat pengelolaan sampahnya. Area tersebut terdiri dari: 1) letak tempat sampah akhir yang sudah dipisahkan yaitu tempat sampah organik dan anorganik; 2) Lokasi Bank Sampah atau tempat penyetoran bank sampah berupa bahan-bahan yang berasal dari plastic; 3) Lokasi tempat pengolahan pupuk. Pengolahan pupuk ini berasal dari sampah rumah tangga atau berupa sampah yang sudah ditentukan untuk kemudian dijadikan pupuk.

\section{Persiapan Mesin Pencacah Sampah}

Tahap kedua adalah persiapan. Tahap ini dimulai dengan mempersiapkan mesin pencacah sampah organik dan anorganik dan memastikan mesin dapat menjalankan proses itu dengan baik. Kemudian kita melakukan modifikasi untuk memperluas muatan sampah sebelum proses pencacahan. Memastikan mesin sebelum dikirim ke lokasi kegiatan.

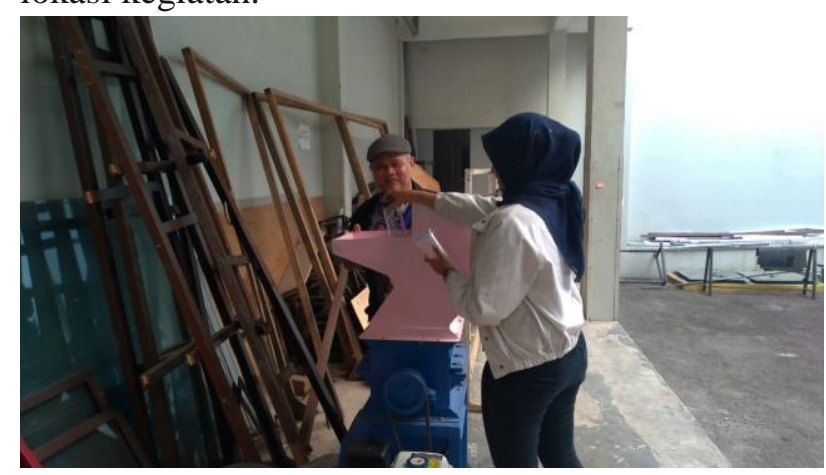

Gambar 2. Proses pengecekan mesin saat sebelum dikirim

Teknologi Tepat Guna 


\section{Sosialisasi}

Sosialisasi dilaksanakan untuk membangun kesadaran masyarakat desa terhadap pentingnya pengelolaan sampah. Proses sosialisasi terdiri dari pemberian materi tentang pengelolaan sampah dan sosialisasi penggunaan alat serta cara pemeliharaannya.

Persiapan materi untuk penyuluhan tentang bagaimana seharusnya pengelolaan sampah yang baik untuk lingkungan Desa Lengkong Kulon. Untuk pelatihan kami membentuk tim pengolahan sampah yang terdiri dari 3 warga Desa Lengkong Kulon yang nantinya akan menjalankan dan memahami bagaimana menjalankan dan merawat mesin dengan baik, agar mesin dapat dipakai dalam jangka waktu yang lama. Materi tersebut disampaikan menggunakan metode presentasi kepada warga yang berkumpul di area Bumdes. Setelah mendapatkan teori tentang pengelolaan sampah, kemudian dilanjutkan dengan pemberian training bagaimana cara menggunakan mesin tersebut termasuk menghitung atau menimbang hasil pencacahan serta proses konversi dari hasil pencacahan menjadi uang yang dapat dimanfaatkan warga sekitar. Berikut adalah tabel rencana kegiatan pelaksanaan PKM di Desa Lengkong Kulon.

Tabel 1. Timeline Pelaksanaan PKM

\begin{tabular}{|l|l|l|l|l|}
\hline No & $\begin{array}{l}\text { Minggu } \\
\text { ke- }\end{array}$ & Waktu & Bulan & Kegiatan \\
\hline 1 & $\begin{array}{l}\text { Minggu } \\
3\end{array}$ & 4 Jam & Maret & Survey lokasi \\
\hline 2 & $\begin{array}{l}\text { MInggu } \\
4\end{array}$ & 4 Jam & Maret & Survey lokasi \\
\hline 3 & $\begin{array}{l}\text { Minggu } \\
1\end{array}$ & 4 Jam & April & $\begin{array}{l}\text { Persiapan } \\
\text { kegiatan }\end{array}$ \\
\hline 4 & $\begin{array}{l}\text { Minggu } \\
2\end{array}$ & 3 Jam & April & $\begin{array}{l}\text { Pembuatan } \\
\text { proposal PKM }\end{array}$ \\
\hline 5 & $\begin{array}{l}\text { Minggu } \\
3\end{array}$ & 3 Jam & April & $\begin{array}{l}\text { Persiapan } \\
\text { pembentukan tim }\end{array}$ \\
\hline 6 & $\begin{array}{l}\text { Minggu } \\
1\end{array}$ & 5 Jam & Mei & $\begin{array}{l}\text { Pemesanan mesin } \\
4\end{array}$ \\
\hline 7 & $\begin{array}{l}\text { Minggu } \\
4 \text { Jam }\end{array}$ & Mei & $\begin{array}{l}\text { Pengecekan } \\
\text { kondisi mesin }\end{array}$ \\
\hline 8 & $\begin{array}{l}\text { Minggu } \\
1\end{array}$ & 3 Jam & Juni & $\begin{array}{l}\text { Pembuatan Materi } \\
\text { penyuluhan } \\
\text { sampah }\end{array}$ \\
\hline
\end{tabular}

\begin{tabular}{|l|l|l|l|l|}
\hline 9 & $\begin{array}{l}\text { Minggu } \\
4\end{array}$ & 3 Jam & Juni & $\begin{array}{l}\text { Percobaan mesin } \\
\text { sampah }\end{array}$ \\
\hline 10 & $\begin{array}{l}\text { Minggu } \\
1\end{array}$ & 4 Jam & Juli & $\begin{array}{l}\text { Proses pengiriman } \\
\text { mesin }\end{array}$ \\
\hline 11 & $\begin{array}{l}\text { Minggu } \\
2\end{array}$ & 5 Jam & Agustus & $\begin{array}{l}\text { Pelatihan dan } \\
\text { pelatihan kepada } \\
\text { warga }\end{array}$ \\
\hline 12 & $\begin{array}{l}\text { Minggu } \\
3\end{array}$ & 1 Jam & Oktober & $\begin{array}{l}\text { Pemantauan } \\
\text { penggunaan } \\
\text { mesin }\end{array}$ \\
\hline 13 & $\begin{array}{l}\text { Minggu } \\
3\end{array}$ & 1 Jam & Januari & $\begin{array}{l}\text { Pemantauan } \\
\text { penggunaan } \\
\text { mesin }\end{array}$ \\
\hline 14 & $\begin{array}{l}\text { Minggu } \\
3\end{array}$ & 1 Jam & Maret & $\begin{array}{l}\text { Evaluasi hasil } \\
\text { akhir }\end{array}$ \\
\hline
\end{tabular}

Menurut tabel 1, Pengujian dan evaluasi hasil dilakukan pada bulan akhir pertemuan pelaksanaan Program Kemitraan Masyarakat. Pengujian dan evaluasinya yaitu melihat perkembangan pengelolaan sampah di Desa Lengkong Kulon, baik di lingkungan sekitar yang tercemar dan lingkungan area pembangunan proyek wisata. Tidak hanya mengevaluasi lingkungan tetapi nantinya kita akan mengevaluasi bagaimana penggunaan mesin yang telah diberikan. Sehingga nantinya setelah proses Program Kemitraan Masyarakat ini selesai dilakukan. Maka pihak Desa Lengkong Kulon sudah siap dan ahli untuk mengelola sampah di lingkungannya tanpa harus repot-repot menghubungi tim pelaksana PKM dari Universitas Multimedia Nusantara.

\section{Pelaksanaan}

Sebagai bentuk usaha dan upaya untuk mendukung tercapainya lingkungan desa yang bersih dan indah dan terhadap pelaksanaan program PKM. Tim melakukan program ini selama 1 Tahun. Pelaksanaannya mulai dari Bulan Maret 2018 sampai Maret 2019. 


\section{HASIL DAN PEMBAHASAN}

1. Lokasi Awal Pembuangan Sampah di Desa
Lengkong Kulon

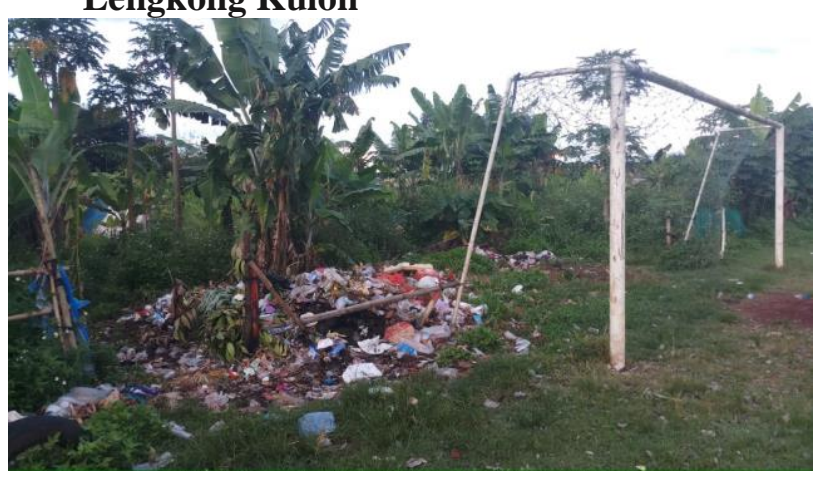

Gambar 3. Tempat pembuangan sampah di lapangan
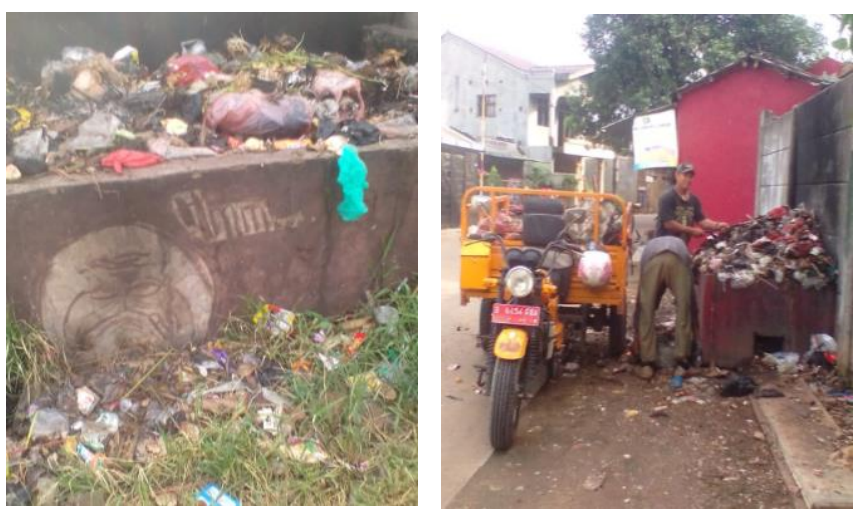

Gambar 4. Tempat pembuangan sampah akhir yang tidak terurus

Pada Gambar 3 dan 4 nampak jelas kondisi sampah disana memang memprihatinkan bagi sebagian RW yang tidak bekerja sama dengan truk pengangkut sampah dari pemerintah daerah setempat. Selain sampah dari masyarakat desa tersebut, ada sampah buangan dari tempat perbelanjaan Q-Big yaitu keranjang buah berbahan dasar plastik. Selain bisa mengolah sampah masyarakat, desa ini memiliki sampah plastik yang bisa diolah dan dapat menghasilkan pundi-pundi rupiah.

\section{Sosialisasi Pentingnya Pengolahan Sampah}

Proses sosialisasi ini terbagi menjadi dua. Sosialisasi pertama berisi penyuluhan tentang jenisjenis sampah, bahaya pencemaran sampah, pentingnya pengelolaan sampah. Berikut merupakan sedikit gambaran tentang materi yang akan disampaikan. Materi ini akan disampaikan oleh Dosen dari Universitas Multimedia Nusantara.

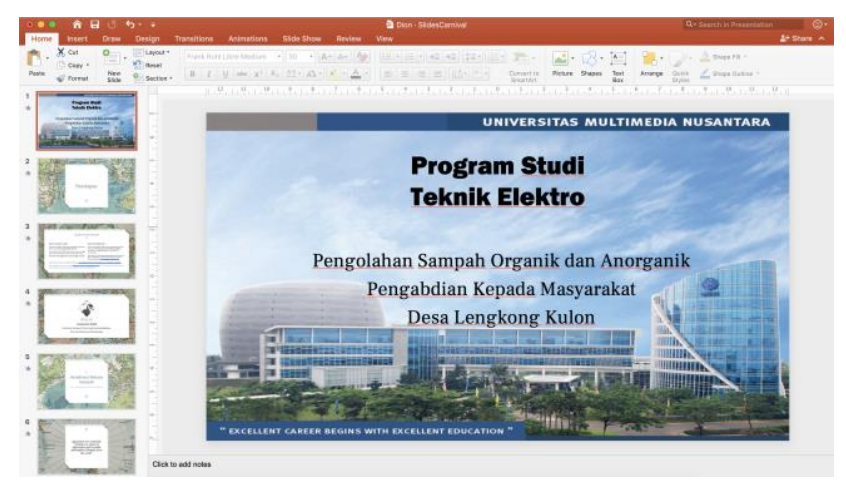

Gambar 5. Materi presentasi pengelolaan sampah

\section{Mesin Pencacah Sampah}

Proses kerjasama PKM ini berbentuk peminjaman mesin pencacah sampah selama satu tahun. =ada gambar 5 berikut ini adalah prosesi serah terima mesin pencacah sampah organik dan anorganik. Prosesi serah terima ini dihadiri oleh Direktur LPPM UMN, Ketua LPPM, Dosen Teknik Elektro, Kepala Desa Lengkong Kulon. 


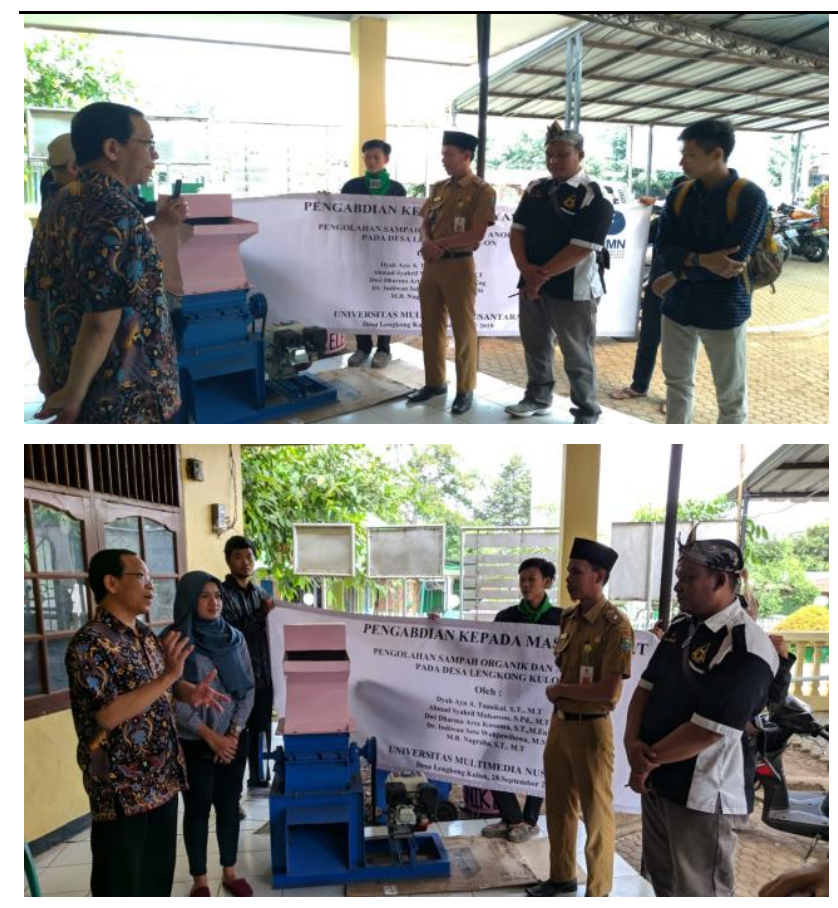

Gambar 6. Prosesi serah terima mesin

Tim menunjuk tiga orang perwakilan, yang ditunjuk oleh Pak kepala desa adalah tiga pemuda yang nantinya akan mengelola dan menjaga mesin pencacah sampah ini. Sebelum menggunakan mesin pencacah sampah ini, terlebih dahulu tiga orang tersebut harus membaca buku petunjuk pemakaiannya. Tim sudah menggambarkan dan mengilustrasikan bagaimana penggunaanya. Pada buku petunjuk terdapat tata cara penggunaan mulai dari menyalakan mesin, petunjuk keselamatan, bagian-bagian mesin, bagaimana cara pengisian bahan bakarnya, petunjuk penyalaan mesin, petunjuk untuk mematikan mesin dan perawatan mesin pencacah sampah. Berikut adalah beberapa bagian dari buku petunjuk tersebut.

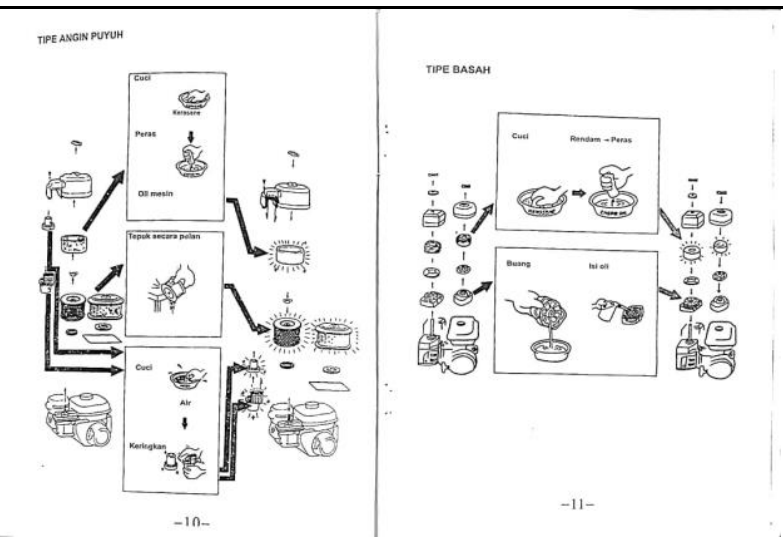

Gambar 7. Bagian-bagian mesin pencacah

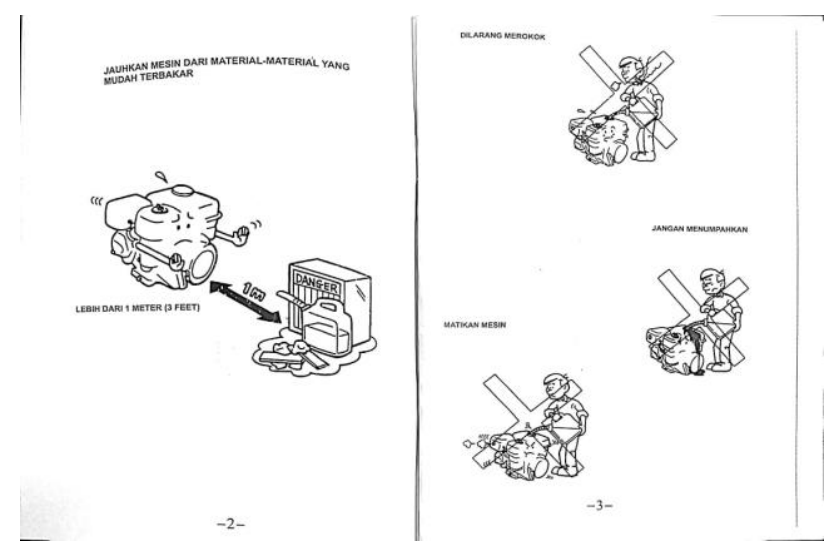

Gambar 8. Petunjuk Keselamatan Kerja

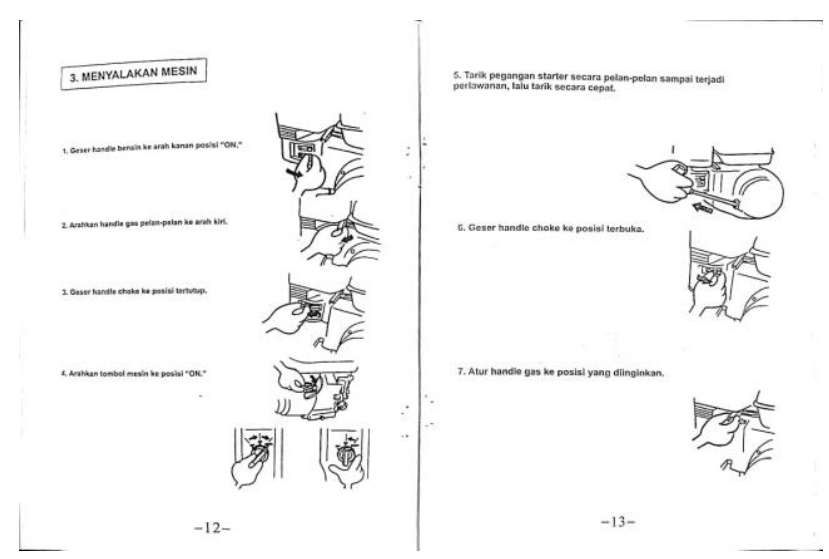

Gambar 9. Petunjuk penyalaan mesin 

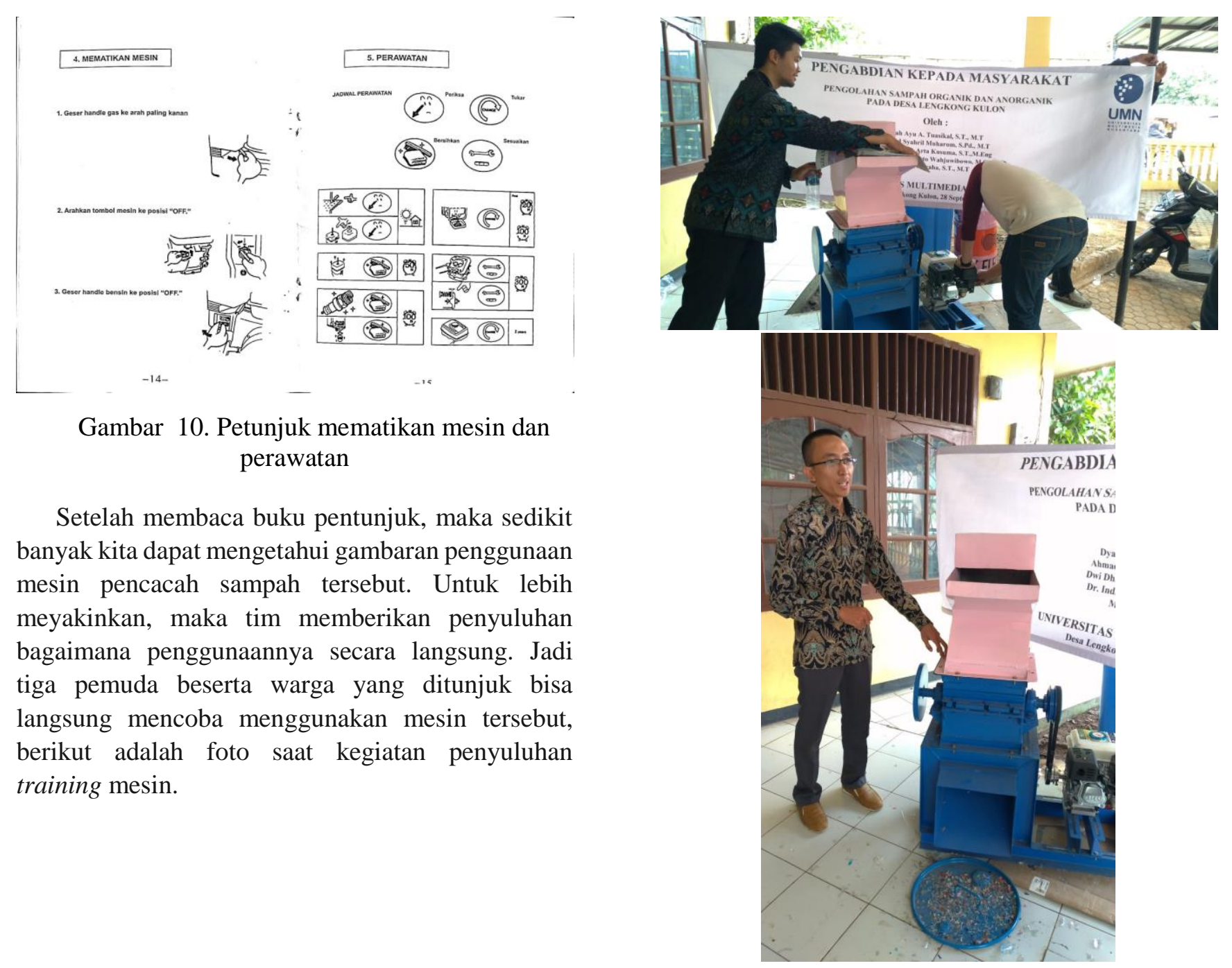

Gambar 11. Penyuluhan penggunaan mesin

Kemudian mesin ini akan dipergunakan untuk mendukung salah satu program desa tersebut yaitu untuk bank sampah. Bank sampah ini akan memproses sampah yang dulunya dibuang sembarangan dan tidak diolah dengan baik akan terorganisir dan dapat dijadikan uang. Kemudian masyarakat akan terbiasa untuk mengumpulkan sampah atau memanfaatkan sampah tersebut dengan baik. Hasil penghancuran plastik menjadi bijih plastik akan lebih meningkatkan nilai jual daripada hanya menjual botol plastik atau beberapa bahan plastik sebelum diolah. 


\section{KESIMPULAN}

Pengelolaan sampah di Desa Lengkong Kulon di kecamatan Pagedangan, Kabupaten Tangerang dilakukan secara optimal yang artinya penggunaan mesin ini dirasakan maksimal oleh warga Desa Lengkong Kulon. Perancanaan selanjutnya akan bekerja sama dengan pihak terkait pengelolaan sampah untuk mendukung perekonomian warga sekitar, misalnya penjualan pupuk cair hasil dari pengolahan sampah tersebut.

Penduduk di Desa lengkong kulon di beberapa RW sudah sadar akan peduli lingkungan melalui sosialisasi pengolahan sampah yang baik.

\section{SARAN}

Dibutuhkan penelitian lanjutan tentang pendalaman tentang proses pengolahan sampah yang dapat mendukung penelitian tentang bahaya pencemnaran lingkungan karena sampah.

\section{UCAPAN TERIMAKASIH}

Terima kasih kepada Prodi Teknik Elektro Universitas Multimedia Nusantara dan LPPM UMN.

\section{REFERENSI}

[1] Data Badan Pusat Statistik Kabupaten
Tangerang. 2018

[2] Departemen Kesehatan Masyarakat RI. 1987. Pembuangan Sampah. Jakarta: Proyek Pengembangan Tenaga Sanitasi Pusat.

[3] Fadhilah A, Sugianto H, Hadi K, Firmandhani SW, Murtini TW, Pandelaki EE. 2011. Kajian Pengelolaan Sampah Kampus Jurusan Arsitektur Fakultas Teknik Universitas Diponegoro. Modul. 11(2): 62-71.

[4] Hadiwijoto S. 1983. Penanganan dan pemanfaatan sampah. Jakarta (ID): Yayasan Idayu.

[5] Lisa, Aisa. 2018. "Enviro School" Rumah Edukasi Pemanfaatan Sampah dalam Rangka Mewujudkan Generasi Peduli Lingkungan. Jurnal Ilmiah Pengabdian Kepada Masyarakat.

[6] Sahil J, Muhdar MHIA, Rohman F, Syamsuri I. 2016. Sistem Pengelolaan dan Upaya Penanggulangan Sampah Di Kelurahan DufaDufa Kota Ternate. Jurnal Bioedukasi. 4(2): 478-487.

[7] Sitanggang, Ch Monica. Perencanaan Sistem Pengelolaan Sampah Terpadu. 2017. Jurnal Teknik Lingkungan, Vol.6, No. 1 (2017) 